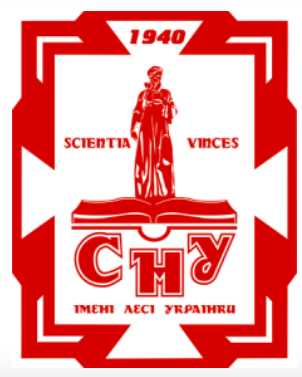

Науковий вісник Східноєвропейського національного університету імені Лесі Украӥнки

Розділ I. Ботаніка

Серія: Біологічні науки, 2019, 4 (388)

\title{
Філогенетичний аналіз деяких таксонів Однодольних за даними порівняльної морфології квітки
}

\section{Оксана Фішук}

Східноєвропейський національний університет імені Лесі Українки, Луцьк, Україна

Адреса для листування: dracaenaok@ukr.net

Отримано: 28.07.19; прийнято до друку: 20.10.19; опубліковано: 27.12.19

Резюме. За даними проведеного еволюційно-морфологічного аналізу квітки досліджуваних таксонів було виявлено 39 ознак, які можна формалізувати й використати для філогенетичного аналізу видів. У числі виявлених ознак є особливості васкулярної анатомії квітки, внутрішньої структури та вертикальної зональності гінецею, структури септального нектарника. Більшість ознак гінецею та васкулярної анатомії квітки використані для кладистичного аналізу вперше. Досліджені представники 11 родів (Sansevieria Thunb., Dracaena Vand. Ex L., Asparagus L., Ruscus L., Polygonatum Mill., Convallaria L., Maianthemum L., Anthericum L., Cordyline Comm. Ex R. Br., Chlorophytum Ker Gawl., Ruscus L.). Еволюційно-морфологічний аналіз і кладистичний аналіз досліджуваних видів дали дещо різні результати щодо спорідненості досліджених таксонів, хоча дозволили сформувати уявлення про чітко виражені рівні організації та морфологічні типи оцвітини, андроцею та гінецею.

Ключові слова: філогенетичний аналіз, гінецей, васкулярна анатомія, вертикальна зональність.

\section{Phylogenetic analysis of some monocotyledon taxa accordingto comparative flower morphology}

\section{Oksana Fishchuk}

LesyaUkrainka Eastern European National University Lutsk, Ukraine

Correspondence: dracaenaok@ukr.net

\begin{abstract}
According to the evolutionary-morphological analysis of the flower by studied taxa, 39 features were identified that will be formalized and used for phylogenetic analysis of the species. Among the features we have discovered there are features of the flower vascular anatomy, the internal structure and vertical zonality of gynoecium, the structure of septal nectar. Most signs of gynoecium and flower vascular anatomy were used for cladistic analysis at the first time.There were study 11 genus (Sansevieria Thunb., Dracaena Vand. Ex L., Asparagus L., Ruscus L., Polygonatum Mill., Convallaria L., Maianthemum L., Anthericum L., Cordyline Comm. Ex R. Br., Chlorophytum Ker Gawl., Ruscus L.). The evolutionary-morphological analysis and cladistic analysis of the studiedspecies gave somedifferent results in relation to the affinity of the studied taxa, although they allowed for the formation of clear organizationlevels and morphological types of perianth, androecium and gynoecium.The cladistic analysis was performed using TNT 1.1. (Goloboff et al., 2008). The search for the optimal and shortest cladogram by the maximum parsimony method was performed by heuristic search.
\end{abstract}

Key words: phylogenetic analysis, gynoecium, vascular anatomy, vertical zonality. 
Lesia Ukrainka Eastern European National University Scientific Bulletin Series:

Biological Sciences, 2019, 4(388)

\section{ВСТУП}

У систематиці однодольних рослин на сьогодні існують два протилежні погляди на обсяг родин підкласу Liliidae, зокрема представників порядку Asparagales. Систематики, які спираються на джерела класичної еволюційної систематики, в тому числі, морфологію, ембріологію, імунологію, фітогеографію виділяють у складі порядку багато дрібних родин $[3,11,12] .3$ іншого боку, за даними молекулярної систематики, багато родин цього порядку виявляють дуже велику подібність та об'єднуються в родину Asparagaceaes. 1. Проблема полягає в тому, що для цієї родини не виявлено жодної морфологічної синапоморфії, тому доцільність об'єднання родин, які добре діагностуються між собою, не $\epsilon$ переконливою, вважають видатні ботаніки світового рівня С. Л. Мосякін та Л. І. Буюн [13].

Морфологічні ознаки для вирішення питань систематики родини Asparagaceae поряд із молекулярними даними вперше використала Пола Рудалл [6]. Нею були задіяні лише три морфологічні ознаки квітки нижня чи верхня зав'язь, наявність септального нектарника, тип плоду, а також використано морфологічні ознаки вегетативного тіла. Нашою метою було оцінити конгруентність ознак зовнішньої та внутрішньої будови квітки (в тому числі мікроморфології гінецею) 3 даними загальної морфології та молекулярної систематики для цієї групи таксонів.

\section{МАТЕРІАЛИ Й МЕТОДИ ДОСЛІДЖЕНЬ}

Мета нашого дослідження полягала в аналізі внутрішньої структури гінецея та виявленні його вертикальної зональності у видів.Матеріал збирали в Ботанічному саду імені академіка О. В. Фоміна Київського національного університету імені Тараса Шевченка (Sansevieria grandicuspis Haw., S. Grandis Hook. f.), Національному Ботанічному саду iм. М. М. Гришка (S. Fernwood Gr., S. Hyacinthoides (L.) Druce., S. aetheopica Thunb., S. Spicata (Cav.) How., S. Parva N. E. Br., S. Suffruticosa N. E. Br., S. Trifasciata Prain, S. Dooneri N. E. Br., Dracaena fragrans (L.) Ker Gawl., D. Surculosa Lindl.), Ботанічному саду Львівського національного університету ім. I. Франка (Rúscus aculeatus L., Asparagus fallax Svent.), на кафедрі ботаніки Східноєвропейського національного університету імені Лесі Українки (Cordyline fruticosa (L.) A. Chev., Asparagus densiflorus (Kunth) Jessop, Gasteria verrucosa (Mill.) H. Duval, Chlorophytum comosum (Thunb.) Jacques), Ботанічному саду Університету м. Грац (Австрія) (Anthericum liliago L.), у природних умовах (Волинська область) (Convallaria majalis L., Polygonatum multiflorum (L.) All., Maianthemum bifolium (L.) F. W. Schmidt) і фіксували у 70\% етанолі. 3 фіксованого матеріалу виготовляли препарати серій поперечних зрізів квітки завтовшки 20 мкм згідно зі стандартною методикою (Барыкина и др. 2004), зрізи зафарбовували розчинами астра-блау та сафраніну. Вивчали п'ять квіток кожного виду. Для вивчення препаратів використовували оптичний мікроскоп марки LABOVAL 4 фірми CARLZEISS (Jena) та бінокуляр марки МБС-10. Рисунки зрізів виготовляли з використанням мікрофотографій, отриманих за допомогою камери марки CANON 1000 D. Висоту зон гінецею обраховували за кількістю поперечних зрізів. Кладистичний аналіз проводили за допомогою програми TNT 1.1. (Goloboffetal., 2008). Пошук оптимальної та найкоротшої кладограми за методом максимальної парсимонії здійснювали шляхом евристичного пошуку. Аналізували 39 морфологічних ознак.

\section{РЕЗУЛЬТАТИ Й ОБГОВОРЕННЯ}

Кодування ознак наведено в таблиці 1.

Ознаки 0-2 - стосуються життєвої форми та загальної морфології рослин, подані за літературними даними $[2,3,6,12]$.

Ознаки 3-13 - зовнішня морфологія квітки, ці ознаки перевірені на досліджуваному матеріалі власноручно, така інформація була відома лише в загальному для родів.

Ознаки 14-25 - мікроморфологія гінецею, дані отримані власноруч. Тут зазначені морфологія гінецею, тип плацентації, особливості внутрішньої структури зав'язі. Ознака 14 - мікроморфологія гінецею, вперше використана для аналізу родини Asparagaceae.

Ознаки 26-30 - ознаки септального нектарника, його вертикальна зональність.

До кладистичного аналізу включені: ознаки мікроморфології гінецею, які виявлені вперше, зональність гінецею за В. Ляйнфельнером, ознаки даху й основи зав'язі та вертикальна зональність септального нектарника.

Ознаки 31-38 - ознаки васкулярної анатомії.

Отже, більшість ознак нові, виявлені вперше i вперше використані для кладистичного 
аналізу. А саме вперше проаналізовано 25 нових ознак: 14-25 - ознаки мікроморфології гінецею, ознаки 26-30 - ознаки будови септального нектарника, його вертикальна зональність та ознаки 31-38 - ознаки васкулярної анатомії квітки.

За результатами аналізу 22 найбільш парсимонічних дерев створена єдина консенсусна кладограма (рис. 1)

\section{ПЕРЕЛІК ВИВЧЕНИХ І ЗАКОДОВАНИХ ОЗНАК (0-38)}

0. Життєва форма: 0 трава, 1 дерево або кущ

1. Листки: 0 не сукулентні, 1 сукулентні

2. Суцвіття: 0 бічне, 1 термінальне

3. Мерність квітки: 0 тричленні, 1 двочленні

4. Тип зав'язі: 0 верхня, 1 нижня або напівнижня

5. Наявність приквітки: $0 €, 1$ нема

6. Наявність приквіточки: $0 €, 1$ нема

7. Наявність зчленування на квітконіжці: 0 нема, $1 \epsilon$

8. Характеристика оцвітини: 0 вільна, 1 трубочка менше $1 / 2$ висоти оцвітини, 2 трубочка $1 / 2$ i більше висоти оцвітини

9. Тичинки: 0 не прирослі до оцвітини, 1 прирослі до оцвітини (до трубочки)

10. Зростання тичинок: 0 не зрослі між собою, 1 зрослі між собою, 2 прирослі до маточки

11. Пиляки: 0 дорзифіксні, 1 базифіксні

12. Розкривання пиляків: 0 латрозне, 1 інтрозне

13. Волосків на оцвітині: 0 нема, $1 \epsilon$

14. Зав'язь: 0 основа + дах зав'язі $=$ або більше висоти гнізд, 1 менше висоти гнізд (від 0,8 і менше).

15. Насінні зачатки: 0 багато, 1 два (або один маргінальний), 2 один у гнізді (медіанний)

16. Наявність обтуратора плацентарного: $0 €, 1$ нема

17. Наявність обтюратора фунікулярного: 0 є, 1 нема

18. Гнізда зав'язі: 0 об'єднуються в одне, 1 ніколи не об'єднуються

19. Канали стовпчика: 0 три, 1 один спільний, 2 два

20. Канали стовпчика: 0 апікальні, 1 субапікальні (зсунуті на вентральний бік)

21. Синасцидіатна зона: $0 €, 1$ нема

22. Гемісинасцидіатна зона: $0 €$ фертильна, 1 є стерильна, 2 нема
23. Гемісимплікатна зона: $0 €$ фертильна, 1 є стерильна, 2 нема

24. Симплікатна зона: 0 нема, $1 €$

25. Початок асимплікатної зони: 0 в стовпчику, 1 в даху зав'язі, 2 на рівні гнізд

26. Септальний нектарник: зона роздільного нектарника: 0 нема, $1 €$

27. Септальний нектарник: 0 нектарна щілина залозиста пряма, 1 нектарна щілина залозиста звивиста або розгалужена, 2 нектарна щілина незалозиста (вивідний канал), 3 нектарна щілина відсутня

28. У септальному нектарнику переважає зона: 0 внутрішнього нектарника, 1 зовнішнього нектарника, 2 відсутній септальний нектарник

29. Септальний нектарник: в основі зав'язі 0 нема, $1 \epsilon$

30. Септальний нектарник: 0 висота рівна або менше гнізд, 1 значно більше гнізд (в 1,5 раза і більше), 2 відсутній септальний нектарник

31. Васкулярна анатомія: сліди тепаліїв 0 не галузяться, 1 галузяться у внутрішніх тепаліях, 2 галузяться в зовнішніх і внутрішніх тепаліях

32. Васкулярна анатомія: сліди тичинок 0 однопучкові, 1 двопучкові

33. Васкулярна анатомія: дорзальні пучки плодолистків 0 без відгалужень, 1 з сліпими відгалуженнями, 23 відгалуженнями, що зливаються 3 вентральними пучками плодолистків

34. Васкулярна анатомія: слід насінного зачатку: 0 однопучковий, 1 двопучковий

35. Васкулярна анатомія: вентральні пучки плодолистків 0 продовжуються вище слідів насінних зачатків і сліпо закінчуються, 1 не продовжуються (повністю використовуються на сліди насінних зачатків), 2 впадають у дорзальні пучки плодолистків над гніздами

36. Васкулярна анатомія: 0 стовбурові пучки у квітколожі розходяться двома колами, 1 шість стовбурових пучків формуються одним колом

37. Васкулярна анатомія: 0 сліди тичинок i листочків оцвітини незалежно формуються, 1 слід листочка оцвітини від тичинки формується у квітколожі, 2 слід листочка оцвітини від тичинки формується у квітковій трубці

38. Васкулярна анатомія: 0 наявність вентральних пучків плодолистка, 1 септальні пучки гінецею $\rightarrow$ вентральні пучки плодолистка, 2 вентральні медіанні пучки плодолистка $\rightarrow$ вентральні пучки плодолистка 


\begin{tabular}{|c|c|c|c|c|c|c|c|c|c|c|c|c|c|c|c|c|c|c|c|c|c|c|}
\hline n & - & 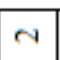 & 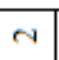 & $N$ & $N$ & $\rightarrow$ & $\neg$ & $\neg$ & 0 & 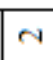 & $\rightarrow$ & $\rightarrow$ & $\rightarrow$ & $\rightarrow$ & $\rightarrow$ & $\rightarrow$ & $\rightarrow$ & $\rightarrow$ & $\rightarrow$ & $\rightarrow$ & $\rightarrow$ & \\
\hline & & & & & & & & & $\rightarrow$ & $\Rightarrow$ & $\rightarrow$ & $\neg$ & 0 & $r$ & $\rightarrow$ & $\rightarrow$ & 4 & 0 & $\rightarrow$ & $\vec{r}$ & $\neg$ & \\
\hline & & & 0 & 0 & 0 & 0 & 0 & 0 & 0 & 0 & $\rightarrow$ & $\rightarrow$ & $\rightarrow$ & $\rightarrow$ & 0 & 0 & 0 & $\rightarrow$ & 0 & 0 & 0 & - \\
\hline$\hat{n}$ & & & $n$ & $\mathrm{c}$ & $c$ & $\mathrm{~N}$ & $N$ & 0 & $N$ & $N$ & 0 & 0 & $N$ & $N$ & $\neg$ & - & $\neg$ & $\neg$ & - & $\neg$ & - & $\sim$ \\
\hline 4 & & & & & & & & & $\neg$ & 0 & $\rightarrow$ & 0 & $\neg$ & 0 & 0 & $\rightarrow$ & - & $\rightarrow$ & $\neg$ & $\rightarrow$ & 0 & $\circ$ \\
\hline$n$ & & & $c$ & $c$ & $c$ & $\rightarrow$ & $\neg$ & $\neg$ & $\neg$ & 0 & $\rightarrow$ & $\rightarrow$ & 0 & $\mathrm{~N}$ & 0 & 0 & 0 & 0 & 0 & 0 & ar & 0 \\
\hline$N$ & & & 0 & 0 & 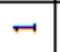 & 0 & 0 & $\rightarrow$ & 0 & 0 & 0 & 0 & 0 & 0 & 0 & 0 & 0 & 0 & 0 & 0 & c. & 0 \\
\hline & & & $\subset$ & $c$ & 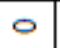 & $\rightarrow$ & $\rightarrow$ & & 0 & $\rightarrow$ & 0 & $\neg$ & $N$ & N & D & 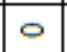 & & $\mathrm{N}$ & $\circ$ & 0 & a. & N \\
\hline 8 & & -7 & $\rightarrow$ & $\neg$ & $\neg$ & $\rightarrow$ & $\rightarrow$ & $\neg$ & $\rightarrow$ & - & $\neg$ & $\neg$ & $\circ$ & 0 & 0 & $p$ & 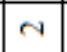 & $N$ & 0 & $\rightarrow$ & $N$ & 0 \\
\hline à & & & - & 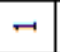 & - & 7 & $\rightarrow$ & $\rightarrow$ & $\rightarrow$ & 0 & 0 & 0 & 0 & 0 & 0 & 0 & 0 & - & 0 & 0 & 0 & 0 \\
\hline$\infty$ & & & $c$ & 0 & $c$ & 0 & 0 & 0 & 0 & 0 & 0 & $\circ$ & 0 & $\circ$ & 0 & 4 & $\checkmark$ & 0 & 0 & 0 & $N$ & $\sim$ \\
\hline 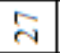 & & - & $\neg$ & $\rightarrow$ & $\neg$ & $c$ & $\neg$ & $\neg$ & $\rightarrow$ & $\rightarrow$ & $\rightarrow$ & $\rightarrow$ & 0 & $\rightarrow$ & $\rightarrow$ & 4 & $n$ & 0 & $\rightarrow$ & 0 & $m$ & $\circ$ \\
\hline 8 & -1 & - & 7 & $\rightarrow$ & $\neg$ & $\neg$ & $\neg$ & $\rightarrow$ & $\neg$ & 0 & - & 0 & $\neg$ & $\neg$ & $\rightarrow$ & 0 & 0 & $\rightarrow$ & $\rightarrow$ & $\neg$ & 0 & - \\
\hline ' & $\mathrm{N}$ & $\mathrm{N}$ & $N$ & $\rightarrow$ & - & $\rightarrow$ & $\rightarrow$ & $\neg$ & $\rightarrow$ & 0 & 0 & $\neg$ & $\rightarrow$ & $\neg$ & $\rightarrow$ & $N$ & - & $N$ & $\rightarrow$ & $\rightarrow$ & 0 & - \\
\hline t & & & $c$ & $c$ & $c$ & $c$ & $\circ$ & $c$ & 0 & 0 & 0 & 0 & $\neg$ & 0 & 0 & $\rightarrow$ & $\neg$ & 0 & 0 & 0 & $\neg$ & o \\
\hline 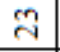 & $N$ & N & $N$ & $N$ & $N$ & $\rightarrow$ & $\rightarrow$ & $\rightarrow$ & $\neg$ & $\neg$ & $\rightarrow$ & - & 0 & $\rightarrow$ & 0 & $N$ & 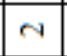 & 0 & 0 & 0 & $N$ & $\circ$ \\
\hline$\widetilde{d}$ & 0 & 0 & 0 & 0 & $\circ$ & 0 & 0 & $\circ$ & 0 & 0 & 0 & 0 & $N$ & A & $N$ & $N$ & 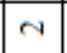 & $N$ & $N$ & $N$ & $N$ & -4 \\
\hline$\vec{a}$ & 0 & $c$ & $c$ & 0 & $c$ & $\circ$ & $\circ$ & $\circ$ & 0 & 0 & 0 & $\circ$ & $\circ$ & 0 & 0 & 0 & 0 & $\circ$ & $\circ$ & 0 & $\rightarrow$ & 0 \\
\hline 8 & 0 & 0 & $\rightarrow$ & $\neg$ & $\rightarrow$ & 0 & $\neg$ & 0 & $\neg$ & 0 & 0 & $\rightarrow$ & $\rightarrow$ & $\rightarrow$ & 0 & $\rightarrow$ & 0 & 0 & 0 & 0 & a. & 0 \\
\hline og & & 0 & 0 & 0 & 0 & c & 0 & 0 & 0 & 0 & 0 & 0 & 0 & 0 & $\neg$ & $N$ & - & $\rightarrow$ & 0 & 0 & 0 & 0 \\
\hline$\infty$ & - & - & - & $\rightarrow$ & 7 & - & $\neg$ & $\rightarrow$ & $\neg$ & $\rightarrow$ & $\rightarrow$ & $\neg$ & $\neg$ & $\neg$ & 0 & $\rightarrow$ & 0 & $\rightarrow$ & $\neg$ & $\neg$ & $\neg$ & - \\
\hline 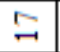 & 0 & 0 & 0 & 0 & 0 & 0 & 0 & 0 & 0 & 0 & 0 & 0 & $\rightarrow$ & 0 & $\neg$ & $\rightarrow$ & $\rightarrow$ & $\rightarrow$ & $\circ$ & 0 & c. & - \\
\hline$\stackrel{0}{2}$ & - & 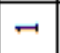 & - & - & - & 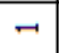 & $\rightarrow$ & $\rightarrow$ & $\neg$ & $\rightarrow$ & $\rightarrow$ & - & 0 & $\neg$ & D & D & D & $\circ$ & $\rightarrow$ & $\neg$ & c. & 0 \\
\hline 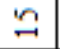 & $\mathrm{r}$ & $\mathrm{c}$ & 0 & 0 & $c$ & $c$ & & & $N$ & $N$ & $N$ & $N$ & $\rightarrow$ & $\rightarrow$ & $\rightarrow$ & $\rightarrow$ & $\rightarrow$ & $\neg$ & $\circ$ & 0 & $\rightarrow$ & $\circ$ \\
\hline$\Xi$ & 0 & $\neg$ & $\rightarrow$ & 0 & $\rightarrow$ & 0 & 0 & $\neg$ & 0 & 0 & $\rightarrow$ & 0 & $\neg$ & $\neg$ & $\neg$ & $\neg$ & $\neg$ & $\rightarrow$ & 0 & $\rightarrow$ & 0 & - \\
\hline 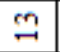 & 0 & 0 & 0 & $\circ$ & 0 & 0 & 0 & 0 & 0 & 10 & 0 & 0 & $\neg$ & 0 & $\rightarrow$ & 0 & 0 & 0 & $\circ$ & 0 & $\rightarrow$ & $\circ$ \\
\hline$\theta$ & 0 & 0 & 0 & 0 & 0 & 0 & 0 & 0 & 0 & 0 & 0 & 0 & $\neg$ & $\rightarrow$ & 0 & 0 & 0 & $\neg$ & $\neg$ & $\neg$ & ar & - \\
\hline$\Xi$ & 0 & 0 & 0 & 0 & 0 & 0 & 0 & 0 & 0 & 0 & 0 & 0 & $\neg$ & $\neg$ & 0 & 0 & $\neg$ & $\rightarrow$ & $\rightarrow$ & $\rightarrow$ & r. & 0 \\
\hline 을 & o & $c$ & $c$ & $c$ & $c$ & c & $c$ & $c$ & 0 & & & & 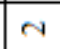 & $\sim$ & 0 & 0 & $\circ$ & 0 & 0 & 0 & $\neg$ & $\circ$ \\
\hline$a$ & - & -1 & $\rightarrow$ & $\rightarrow$ & - & $\neg$ & $\rightarrow$ & $\rightarrow$ & - & $\rightarrow$ & $\rightarrow$ & $\rightarrow$ & 0 & $\rightarrow$ & $\rightarrow$ & ๑ & م & 0 & $\rightarrow$ & $\rightarrow$ & 0 & $\circ$ \\
\hline$\infty$ & - & & & - & & & $\mathrm{N}$ & $\rightarrow$ & $a$ & $\rightarrow$ & $\rightarrow$ & $\mathrm{N}$ & 0 & $\rightarrow$ & $\Leftrightarrow$ & f & & & $\neg$ & $\rightarrow$ & & \\
\hline N & - & -1 & $\Rightarrow$ & $\rightarrow$ & $\Rightarrow$ & $\rightarrow$ & $\rightarrow$ & $\rightarrow$ & - & $\neg$ & $\rightarrow$ & $\neg$ & $\rightarrow$ & - & 0 & 0 & $\neg$ & - & $\rightarrow$ & $\rightarrow$ & c. & $\circ$ \\
\hline a & & & & 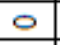 & & & & $c$ & 0 & 0 & 0 & 으 & $\rightarrow$ & 으 & - & 0 & & & 0 & 0 & 0 & 으 \\
\hline n & 0 & 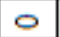 & & & & & & & & & & & & & & & & & & & & - \\
\hline d & & & & $c$ & & & & $c$ & $c$ & 0 & 0 & & 0 & c & 8 & 0 & 0 & & $\circ$ & 0 & $\rightarrow$ & 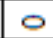 \\
\hline$m$ & 0 & $c$ & 을 & c & $c$ & $c$ & $c$ & $c$ & $c$ & 0 & 0 & 0 & $\circ$ & $\circ$ & $\circ$ & -7 & 0 & $\circ$ & $\circ$ & $\circ$ & $\circ$ & $\circ$ \\
\hline $\mathrm{N}$ & & & - & & & $\neg$ & $\rightarrow$ & $\rightarrow$ & 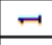 & - & $\rightarrow$ & $\rightarrow$ & $\rightarrow$ & 工 & 으 & 0 & 0 & 은 & 웅 & $\circ$ & $\circ$ & 으 \\
\hline- & - & - & - & - & & & & - & - & - & c & & 0 & & & & & & $c$ & & & - \\
\hline e & 으 & $c$ & 으 & $c$ & $c$ & 으 & & $\circ$ & $c$ & $\circ$ & $1-$ & 5 & $c$ & 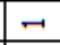 & $\circ$ & 2 & & ㅇ & $\circ$ & & $\rightarrow$ & 0 \\
\hline & 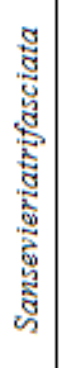 & 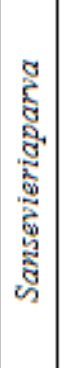 & 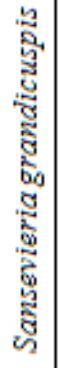 & 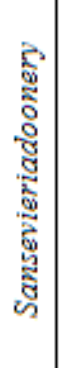 & 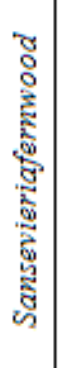 & 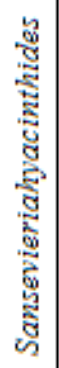 & 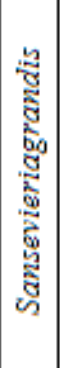 & 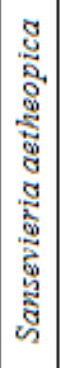 & 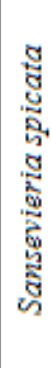 & 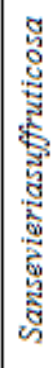 & 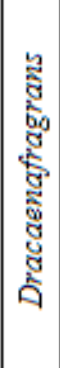 & 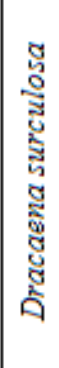 & 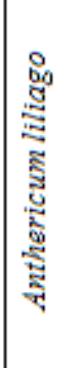 & 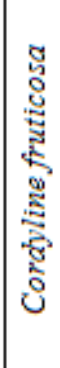 & 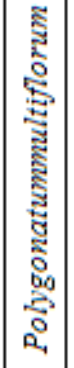 & 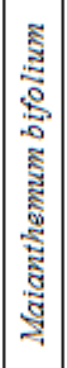 & 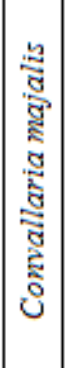 & 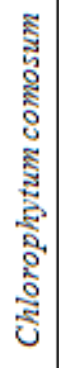 & 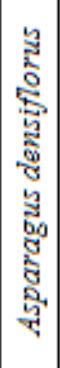 & 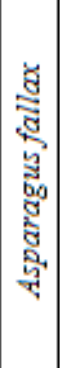 & 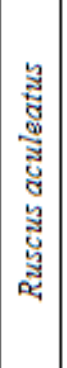 & 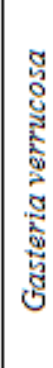 \\
\hline 원 & $\rightarrow$ & $\sim$ & m & + & $"$ & 0 & r & $\infty$ & $a$ & 으 & $\exists$ & $\Xi$ & $\cong$ & 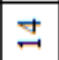 & $\because$ & $\stackrel{0}{-1}$ & $\Xi$ & $\stackrel{\infty}{\sim}$ & $\stackrel{2}{a}$ & 소 & $\vec{N}$ & \\
\hline
\end{tabular}


За результатами проведеного нами кладистичного аналізу (рис. 1) підтверджується монофілія родини Asparagaceaes. 1. зі 100\% підтримкою, проте жодної синапоморфії для цієї родини не виявлено (рис. 2).

Також підтверджена монофілія гілки Sansevieria+Dracaena, яка має підтримку 100\% і включає монофілетичну групу 3 двох видів Dracaena, підтримка якої - $81 \%$ (рис. 1). Синапоморфіями для роду Dracaena є життєва форма (деревоподібні рослини), відсутність сукулентних листків, вентральні пучки плодолистків продовжуються вище слідів насінних зачатків і сліпо закінчуються у зав'язі, одночасно розходяться шість провідних пучків зовнішніх і внутрішніх листочків оцвітини (ознаки 0, 1, 35, 36). Види роду Dracaena є сестринською групою до S. suffruticosa за відсутністю септального нектарника в основі зав'язі (ознака 29).

Одна 3 гілок групи Sansevieria+Dracaena 3 посередньою підтримкою 59\% об'єднує п'ять видів роду Sansevieria (S. fernwood, S. dooneri, S. trifasciata, S. parva, S. grandicuspis) 3 найменшими розмірами квітки.

Синапоморфіями для цієї групи $\epsilon$ відсутність гемісимплікатної зони гінецею та початок асимплікатної зони на рівні гнізд (ознаки 23, 25). Цікаво, що в цю групу потрапили види Sansevieria 3 меншим діаметром квіткової трубки та спільною структурою гінецею. В межах цієї групи $S$. fernwood та S. Dooneri є сестринськими групами.

Решта видів Sansevieria формують гребінчасту структуру та об'єднують сансев'єрії з великими розмірами квіток. Вони формують невирішену частину кладограми.

Другим важливим результатом нашого аналізу є підтвердження монофілії групи родів $[$ Ruscus +Convallaria $]+$ Maianthemum+Polygonatum] за латрозним розкриванням пиляків (ознака 12). Група Ruscus +Convallaria виділяється 3 підтримкою $81 \%$ та однією синапоморфією - відсутність септального нектарника (ознака 30). Роди Ruscus, Convallaria, Maianthemum, Polygonatum дуже відмінні між собою за структурною організацією квітки та за структурою гінецею зокрема (тримерна або димерна квітка, довга або відсутня квіткова трубка, тичинки прирослі до трубки, вільні або зрослі між собою, септальний нектарник наявний або відсутній). Ці роди являють собою декілька еволюційних гілок за напрямом

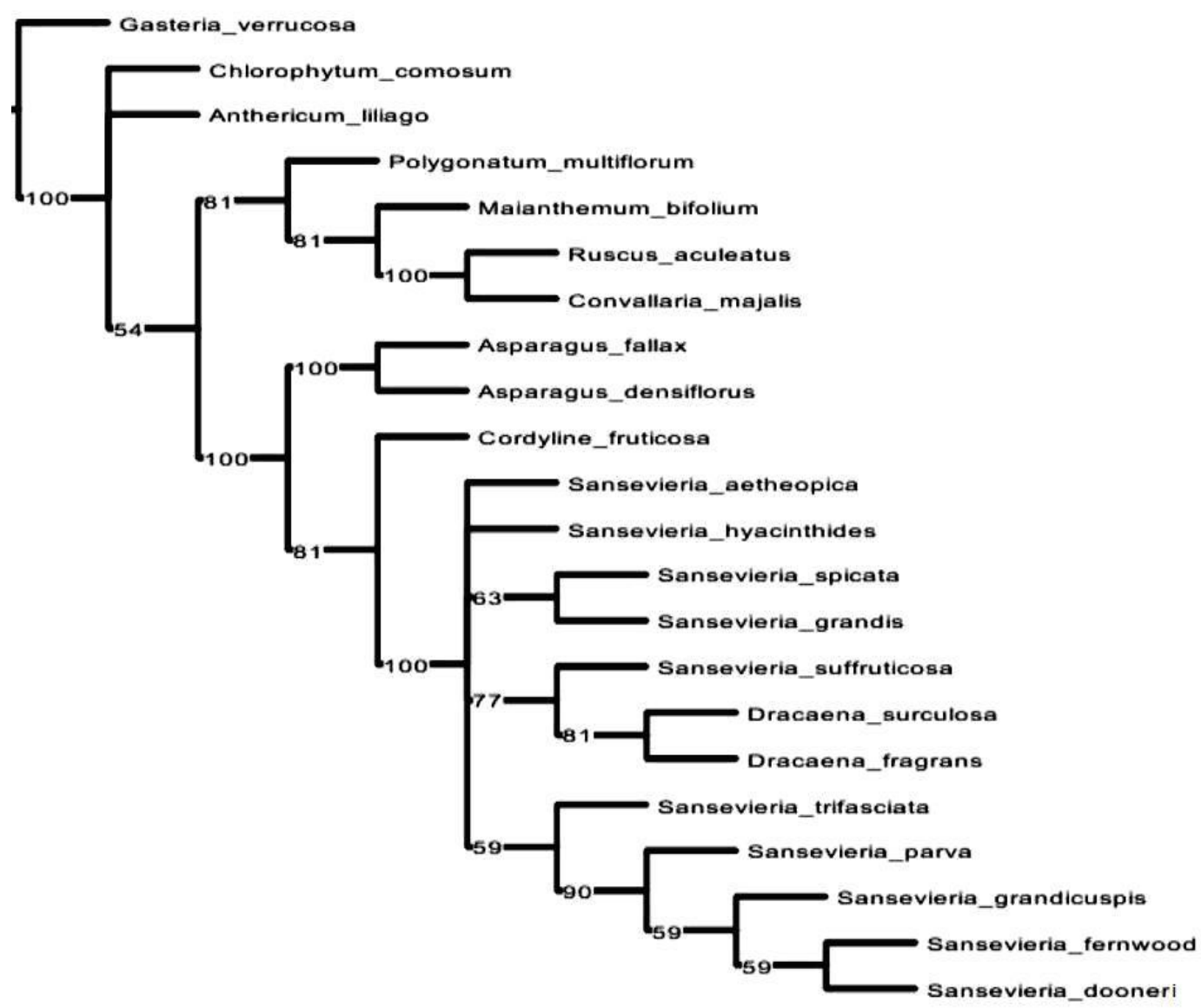

Рис. 1. Консенсусна кладограма досліджених таксонів за результатами часткового консенсуса (представлено гілки, які мають більше 50\% підтримки) 
Філогенетичний аналіз деяких таксонів Однодольних за даними порівняльної морфологї̈ квітки

спеціалізації гінецею, вихідним типом для яких є рід Polygonatum. У роді Ruscus будова гінецею відрізняється від усіх інших досліджених родів у зв'язку 3 псевдомовномерією, яка потребує подальшого вивчення.

Maianthemum bifolium - сестринська гілка до [Ruscus +Convallaria], найбільш відрізняється від них за будовою гінецею, це пов'язане з тим, що Maianthemum bifolium - ефемероїд 3 редукованою квіткою, який має вкорочений життєвий цикл. За молекулярними даними [6], Maianthemum bifolium розміщується серед Convallaria та Polygonatum, тому розміщення цього виду на нашій кладограмі не є остаточним.

За сукупністю морфологічних ознак гінецею рід Polygonatum найбільш подібний до родів Sansevieria та Dracaena (вертикальна зональність гінецею за В. Ляйнфельнером, довгий септальний нектарник, потовщені основа i дах зав'язі). Незважаючи на різноманіття структурних ознак, за аналізом сукупності досліджених ознак всі ці роди потрапили в одну філогенетичну гілку, яка відповідає обсягу родини Ruscaceaes. str. [6]. Синапоморфією для представників роду Asparagus 3 підтримкою у 100\% є кількість насінних зачатків у гнізді два і більше (ознака 15). Проте велика парна кількість насінних зачатків характерна i для базальних груп родини Asparagaceae - родів Gasteria, Chlorophytum, а також Cordyline. Розміщення роду Asparagus на нашій кладограмі не підтверджується молекулярними даними [6], тому необхідним $є$ пошук інших ознак для більш точного визначення кола споріднених таксонів цього роду.

Сестринською до групи Dracaena+ Sansevieria виявилась Cordyline fruticosa, за двома синапоморфіями - наявність термінального суцвіття (ознака 2) та наявність стерильної гемісимплікатної зони (ознака 23), що узгоджується $з$ даними Л. І. Іваніної [14], але суперечить молекулярним даним [1, 7, 13, 8-10].

Роди Anthericum та Chlorophytum займають базальне місце в родині Asparagaceae s. 1. Для роду Anthericum апоморфіями є наявність термінального суцвіття (ознака 2), відсутність приквіточки (ознака 6), тичинки прирослі до маточки (ознака 10), наявність волосків на оцвітині (ознака 13), субапікальні канали стовпчика (ознака 20) та наявність симплікатної зони (ознака 24) (рис. 2). Для роду Chlorophytum апоморфіями $є$ наявність одного спільного каналу стовпчика (ознака 19), початок асимплікатної зони на рівні гнізд (ознака 25), наявність септального нектарника в

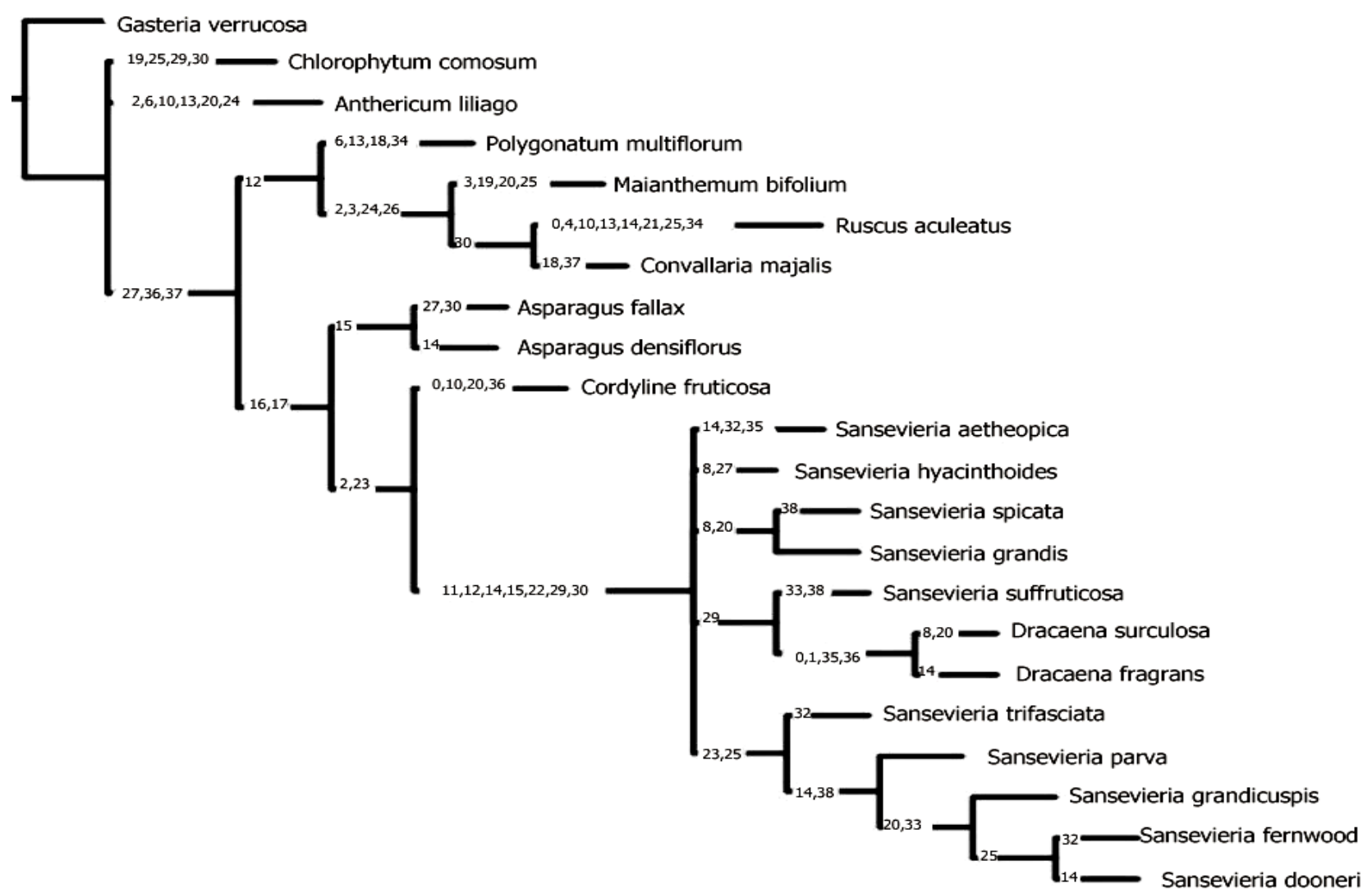

Рис. 2. Консенсусна кладограма спорідненості роду Sansevieria Thunb. та споріднених таксонів із зазначеними синапоморфіями 
основі зав’язі (ознака 29) та висота септального нектарника значно більше гнізд (в 1,5 раза i більше) (ознака 30).

За результатами еволюційно-морфологічного та філогенетичного аналізу ми вважаємо, що рід Dracaena похідний від роду Sansevieria. На жаль, наявні дані стосовно роду Dracaena не можуть підтвердити чи спростувати наше твердження [4, 5]. Ми припускаємо, що рід Dracaena може виявитися поліфілетичним, але це наше припущення обмежене тим, що було досліджено лише два види цього роду. Підтвердження чи спростування цієї тези потребує подальших досліджень. Зокрема, на іiі користь свідчать виявлені нами факти, а саме: різна вертикальна зональність гінекею Dracaena fragrans i Dracaena surculosa, різне співвідношення довжини квіткової трубки, різна висота септального нектарника.

Доказом того, що Dracaena є похідною від роду Sansevieria, може служити той факт, що рід Sansevieria - трав'яні рослини, а Dracaena дерева [2]. Похідний характер деревної життєвої форми узгоджується 3 уявленнями еволюційної морфології [12, 15] і пов'язаний 3 розвитком вторинно деревних форм росту за рахунок нетипового вторинного потовщення осьових органів у представників роду Dracaena [15].

За визначеною нами системою [7], Anthericum liliago та Chlorophytum comosum належать до підродини Agavoideae i не $\epsilon$ сестринською групою, але близько розміщені у кладограмі і не мають спільних апоморфій.

Gasteria verrucosa була взята нами як зовнішня група 3 родини Хanthorrhoeaceae, у філогенетичному дереві вона утворює окрему гілку, яка відрізняється від інших родів тим, що має найбільшу кількість насінних зачатків, не потовщені основу i дах зав'язі, найбільш зигоморфну оцвітину та квіткову трубку, утворену без участі тичинок.

\section{ВИСНОВКИ}

Отже, за результатами кладистичного аналізу, проведеного за морфологічними й анатомічними ознаками, які переважно були виявлені у нашому дослідженні, підтверджується монофілія групи Dracaena+Sansevieria. Представники роду Dracaena (Dracaena fragrans i Dracaena surculosa) формують монофілетичну гілку в межах цієї групи. В межах роду Sansevieria виділяється монофілетична група видів із найменшим розміром квіток (S. trifasciata, S. parva, S. grandicuspis, S. fernwood, S. dooneri). Підтверджена монофілія групи [Ruscus+Convallaria $]$ Maianthemum+Polygonatum], а також монофілія родини Asparagaceaes. 1. Як i в наших попередників, наш аналіз не дозволив встановити жодної апоморфії для цієї родини, незважаючи на підтримку 100\%.

Загалом наші дані лише частково узгоджуються 3 даними молекулярної систематики, а саме $\epsilon$ конгруентність в оцінці монофілії групи Convallariaceae / Ruscaceae (Ruscus, Convallaria, Maianthemum, Polygonatum) за відсутністю або частковою редукцією септального нектарника, за відсутністю гемісинасцидіатної зони зав'язі та групи Dracaena+Sansevieria за наявністю квіткової трубки, довгого септального нектарника та родини Asparagaceae s. 1. Проте розміщення груп Dracaenaтa Ruscus $\epsilon$ на нашій кладограмі дискусійним, як i $і$ х спорідненість 3 родами Cordyline та Asparagus. Це свідчить про те, що використані нами морфологічні ознаки не були абсолютно позбавлені від гомоплазії і що в родині Asparagaceae s. 1. еволюція морфологічних та анатомічних ознак квітки не була однонаправленою. Отриману нами кладограму можна розглядати лише як один із способів інтерпретації морфологічних ознак квітки для цілей систематики родини Asparagaceaes. 1.

Наші дані 3 еволюційно-морфологічного аналізу квітки та філогенетичного аналізу представників родини Asparagaceae s. 1. підтверджують правомірність виділення монофілетичних родин Dracaenaceae (Sansevieria та Dracaena), Ruscaceaes. str. / Convallariaceae (Polygonatum, Maianthemum, Ruscus, Convallaria), та Asparagaceaes. str. (Asparagus), а також можливість розглядати родину Asparagaceae s. 1. як монофілетичну групу в широкому розумінні, базальною в якій $\epsilon$ підродина Agavoideae. Використання ознак мікроморфології та васкулярної анатомії квітки, особливо гінецею із септальним нектарником, у систематиці родини Asparagaceae s. 1. є виправданим на рівні підродин або родин у вузькому тлумаченні.

\section{ЛIТЕРАТУРА}

1. Bogler, D. J. Phylogeny of Agavaceae based on ITS rDNA sequence variation Amer. J. Bot. 1996, Vol. 83, pp 1225-1235. 
2. Bos, J. J. Dracaenaceae In: K. Kubitzki et al. (ed.), The families and genera of vascular plants. III. Flowering plants. Monocotyledons: Lilianae (except Orchidaceae). Springer. 1998, pp 238-241.

3. Kubitzki, K. Systematics and Evolution. The families and genera of vascular plants. 1998, Vol. III, $478 \mathrm{p}$.

4. Lu, P.-L. Phylogenetics of the plant genera Dracaena and Pleomele (Asparagaceae). Botanica Orientalis - Journal of Plant Science. 2010, Vol. 7, pp 64-72.

5. Lu, P.-L. Phylogenetic Relationships among Dracaenoid Genera (Asparagaceae: Nolinoideae) Inferred from Chloroplast DNA Loci. Systematic Botany. 2014, Vol. 39, № 1, pp 90-104.

6. Rudall, P. J.; Conran, J. G.; Chase, M. W. Systematics of Ruscaceae, Convallariaceae: a combined morphological and molecular investigation. Bot. J. Linn. Soc. 2000, Vol. 13, № 4, pp 73-92.

7. Stevens, P. F. Angiosperm Phylogeny Website.

8. Theangiosperm phylogeny group. An ordinal classification for the Families of Flowering Plants (APG). Ann. Missouri Bot. Garden. 1998, Vol. 85, № 4, pp 531-553.
9. Theangiosperm phylogeny group. An update of the angiosperm phylogeny group classification for the orders and families of flowering plants (APG II). Bot. $J$. Linnean Soc., London. 2003, Vol.141, №4, pp 399-436.

10. Theangiosperm phylogeny group. An update of the angiosperm phylogeny group classification for the orders and families of flowering plants (APG III). Bot. J. Linnean Soc. 2009, 161, № 2, pp 105-121.

11. Thorne, R. F. An Updated Classifacation of the Class Magnoliopsida 2. The Botanical Review. The New York Botanical Garden. 2007, pp 67-182.

12. Takhtajan, A. Flowering plants. Springer. 2009, 871 p.

13. Мосякін, С. Л.; Буюн, Л. І. Проблема Asparagales sensu APG: сучасні погляди на макросистематику ключової групи однодольних. Фундаментальні та прикладні аспекти сучасної орхідології. Книгоноша: Київ, 2014. с 119-128.

14. Иванина, Л. И. Семейство драценовые (Dracaenaceae). Жизнь растений: В 6-ти томах. Под ред. А. Л. Тахтаджяна. Просвещение: М., 1982, Т. $6,543 \mathrm{c}$.

15. Тахтаджян, А. Л. Система и филогения цветковых растений. Наука: М., Л., 1966, 611 с. 